
SYLWIA BYKOWSKA

The Impact of World War II on the Population of Gdańsk 
SYLWIA BYKOWSKA

INSTITUTE OF HISTORY, POLISH ACADEMY OF SCIENCES

UDC 314.1(438Gdansk):94(438)>“1939/1945"

https://doi.org/10.32728/flux.2019.1.7

Review article

\section{The Impact of World War II on the Population of Gdańsk}

The article discusses the impact of World War II on the fortunes of the population of Gdańsk, which was incorporated into Poland together with eastern parts of Germany. The development of ethnic relationships in the areas described in post-war Poland as the "regained territories" was determined by the national idea. The German population was resettled, whilst the people of the Polish-German borderlands had to prove their ethnic usefulness by means of ethnic vetting. In Gdańsk, this applied mainly to the inhabitants of the pre-war Free City of Danzig. 
The political situation in Europe at the end of World War II was determined by the decisions reached at the Yalta and Potsdam conferences. ${ }^{1}$ The political division of Europe into East and West, made at that time, lasted for half a century and placed Poland in the sphere of influence of the Soviet Union. The decisions reached at those conferences created new borders for Poland. At the Potsdam conference in 1945, the great powers resolved that Gdańsk and the eastern provinces of Germany would be annexed to Poland. ${ }^{2} A t$ the same time, Poland lost her pre-war eastern territories to the USSR. ${ }^{3}$ Many countries of Central and Eastern Europe had to alter their political shape, a situation marked by ethnic cleansing, including resettlement, deportation and segregation of the population. ${ }^{4}$ Authoritarian political regimes were installed, exploiting nationalist ideology in order to introduce a new order. ${ }^{5}$

This article will show how World War II affected the history of the population of Gdańsk - the city where this armed conflict broke out. Following World War I, Gdańsk was the subject of a political dispute between Germany and Poland. Both countries claimed a right to this city, which was ultimately granted the status of a Free City. ${ }^{6}$ This political organism came to an end when the Third Reich invaded Poland on September 1, 1939. ${ }^{7}$ After the war, Gdańsk was regarded as a former German city, which meant that it was part of Poland's so-called regained territories ${ }^{8}$. That is how the communist authorities described these areas in order to underscore their links to Poland in the past. Therefore, this expression was used to justify the changes to the border, and at the same time underlined the triumph of the Red Army which, having defeated Nazism, won for Poland her rightful historical territories. The resultant propaganda theory of "historic justice" was propagated for

1 See: Krystyna Kersten, Jałta w polskiej perspektywie (Warsaw: Wydawnictwo ANEKS \& NOWa 1989); Antoni Czubiński, Polska i Polacy po Il wojnie światowej (1945-1989) (Poznań: Wydawnictwo Naukowe UAM 1998).

2 The regained territories consisted of the following areas: Silesia, the Lubusz area, Western Pomerania with Szczecin and Eastern Pomerania with Gdańsk, and the southern part of East Prussia, i.e. Warmia and Mazuria. Poland's western border ran along the Oder and Lusatian Neisse rivers. See Czesław Osękowski, Społeczeństwo Polski Zachodniej i Północnej w latach 1945-1956: procesy integracji i dezintegracji (Zielona Góra: WSP, 1994); Maciej Hejger, Przekształcenia narodowościowe na ziemiach zachodnich i północnych Polski w latach 19451959 (Słupsk: Wydawnictwo Naukowe Akademii Pomorskiej, 2008). Today's stabilisation of Poland's western and northern territories derives from the treaties concluded between united Germany and the sovereign Republic of Poland in 1990 and 1991 on the common border along the Oder and Neisse rivers, the principles of good-neighbourliness and cooperation, and Poland's aims to join Western Europe's political-defensive and economic structures. These finally confirmed the Polish state's independence from the Soviet Union, and later Russia. The Northern Group of Red Army Forces, formed in 1945 and stationed in Poland until 1993, had one of its largest bases in Pomerania.

3 These areas are: the western parts of Lithuania, Byelorussia and Ukraine. In Polish historical narrative, they are called the Eastern Borderlands.

4 See Piotr Eberhardt, Między Rosja a Niemcami. Przemiany narodowościowe w Europie Środkowo-Wschodniej w XX w. (Warsaw: PWN, 1996).

5 Piotr Madajczyk, Czystki etniczne i klasowe w Europie XX wieku. Szkice do problemu (Warsaw: Instytut Studiów Politycznych PAN, 2010).

6 See Stanisław Mikos, Wolne Miasto Gdańsk a Liga Narodów: 1920-1939. (Gdańsk: Wydawnictwo Morskie 1979).

7 See Andrzej Drzycimski, Westerplatte: misja specjalna (Gdańsk: Oficyna Gdańska, 2015).

8 See Czesław Osękowski and Grzegorz Strauchold, eds., "Ziemie Odzyskane" po drugiej wojnie światowej (Zielona Góra: Oficyna Wydawnicza Uniwersytetu Zielonogórskiego, 2015). 
successive decades after the war.

As Timothy Snyder wrote, Stalin wanted to make Poland the centre of an ethnically pure zone. ${ }^{9}$ The countries of Central and Eastern Europe were seized with the idea of rebuilding their states free of the destructive impact of ethnic minorities. ${ }^{10}$ In Poland, particularly affected by the years of occupation and ethnic conflicts, the concept of "nation" assumed sharp contours. A radical way of thinking emerged, in which the idea of nation corresponded to raison d'état, which sometimes served as an excuse for brutal measures. The objective of the Polish authorities soon after the war was to create an ethnically homogenous state, involving rapid ethnic changes and including the removal of minorities. Persons other than Polish nationals were perceived as a threat to the state, and actions were taken against them that involved entire communities. Ethnic purges were carried out in the border areas: compulsory resettlement was imposed on Germans in the east and to Ukrainians in the south-east of Poland."

The first authorities in the "regained territories" were Red Army kommandaturas. ${ }^{12}$ Gdańsk was captured on March 30, 1945 when, after 21 days of shelling and bombardment, Soviet and Polish forces liberated the city which had become a fortress since Hitler's order that it must be defended to the last man. The Military Council of the II Byelorussian Front immediately installed a district kommandatura, headed by Lieutenant-General Syemion Mikulskiy. He was responsible for, among other things, a normalisation of the economic situation and ethnic policy. The government groups charged with taking over administration of the city reported to him. This marked a new chapter in the history of Gdańsk.

The capture of Gdańsk by Soviet and Polish forces commenced a period of Polonising every element - institutions, public life, the population and local historical interpretation. ${ }^{13} \mathrm{~A}$ clear role in this regard was assigned to the indigenous Polish population of Gdańsk and Pomerania, ${ }^{14}$ and likewise

9 Timothy Snyder, Bloodlands. Europe between Hitler and Stalin (New York: Basic Books, 2010), 313.

10 As Madajczyk and Berlińska have written: "The Soviet sphere of influence was not homogenous, but was torn by ethnic conflicts which hampered control over it. These conflicts increased during the war. One need only recall the Polish-Ukrainian, SlovakHungarian and Serbian-Croatian conflicts." Danuta Berlińska and Piotr Madajczyk, Polska jako państwo narodowe. Historia i pamięć (Warsaw-Opole: Instytut Studiów Politycznych PAN, 2008), 238.

11 Berlińska, Madajczyk, Polska jako państwo narodowe, 143.

12 The Soviets treated Gdańsk as a conquered city and applied the principle of spoils of war, removing industrial plant and deporting Germans and persons considered to be Germans into the depths of the USSR to perform forced labour. Anyone found to have German or Gdańsk identity documents was arrested. Regardless of the fact that many of them were of Polish descent, they were sent to the mines in distant Siberia. Some 10000 Gdańsk Germans are believed to have been deported. Five thousand of them never returned. Gerhard Reichling, Die Deutschen Vertriebenen in Zahlen. Teil I: Umsiedler, Verschleppte, Vertriebene, Aussiedler 1940-1985(Bonn: Kulturstiftung der Deutschen Vertriebenen, 1986), 33.

13 Just as the German authorities once talked of re-Germanisation, so the Polish authorities now described the incorporation of Gdańsk into Poland as re-Polonisation.

14 This refers to the indigenous population of Polish origin that had inhabited the area of Gdańsk and Pomerania for many decades. This term also included the local ethnic group - Kashubians. Another term coined by the authorities to describe groups form the PolishGerman borderlands (in a pejorative sense) was autochthons - citizens of the Third Reich 
to the indigenous Poles inhabiting former German territories now annexed to Poland. The obsession with restoring the Polishness of former German territory did not go hand in hand with satisfying the needs of persons of Polish descent who formed part of the indigenous population. ${ }^{15}$ The specific nature of this society was that it lived in border zones and was strongly attached to the local area, regardless of the country to which it belonged.

It is a historical paradox that Gdańsk, hitherto inhabited mainly by Germans, became a goal for Polish settlers after the war. There are historical and political reasons for this. For centuries, Gdańsk was a subject of Polish claims, and during the period in which it was a Free City it had close associations with Poland, laid down in special agreements. ${ }^{16}$ Furthermore, the fact that the war started in Gdańsk and the martyr-like image of Polish soldiers and defenders of the Post Office possessed great symbolism. ${ }^{17}$ In the minds of Poles, Gdańsk was Polish, or at least Poland was entitled to it. Thus, the deportation of the entire German population was the first step in the process of Polonisation. The next steps included settling and managing Gdańsk, removing all evidence of Germany, and imparting to the city a Polish character.

In pursuance of the idea of an ethnic state, all Germans demonstrating German nationality were to be removed from Poland. In the "regained territories", these were mainly persons holding German citizenship, excluding people who had proved their Polish descent during the process of ethnic vetting. In the remaining parts of Poland, Polish citizens who had voluntarily enrolled themselves in the German Volksliste during the war were also subject to resettlement.

As Timothy Snyder, whom I mentioned above, correctly wrote:

Hitler's own policies of moving Germans during the war suggested how Germans might be treated thereafter. German wartime colonization made a certain amount of forced population transfers seem inevitable. The only questions were how many Germans, and from which territories. ${ }^{18}$

The deportation of Germans from Poland, including from Gdańsk, occurred in several stages and was dependent on the decisions of the Allied Control Council for Germany in Berlin. The operation was conducted on the basis of a Polish-British agreement of February 14, 1946 and Polish-Soviet agreements of May 5, 1946 and April 12, 1947. The German transports were arranged by the State Repatriation Office, local authorities and the army and the security service. One responsible for the smoothness of the operation was Józef Jaroszek, the Chief Delegate for the Repatriation of the German

who claimed Polish descent. See Andrzej Sakson, Mazurzy - społeczność pogranicza (Poznań: Instytut Zachodni, 1990).

15 See Grzegorz Strauchold, Autochtoni polscy, niemieccy, czy...od nacjonalizmu do komunizmu (1945-1949)(Toruń: Wydawnictwo Adam Marszalek, 2001).

16 For example, the area of the Free City of Danzig was part of the customs zone of the Second Republic, moreover Poland had the right to export and import goods via the maritime port of Gdańsk and to have her own postal, telephone and telegraph services.

17 World War II broke out when the fort of Westerplatte and the post office in Gdańsk were simultaneously attacked on September 1, 1939.

18 Timothy Snyder, Bloodlands, 313. 


\section{Population. ${ }^{19}$}

But before the planned resettlements commenced, there was a series of spontaneous evictions of Germans in 1945 in order to seize their property. ${ }^{20}$ Many Germans left Gdańsk individually in order to escape persecution. Most of the Germans in Gdańsk left the city during the first few months after the war. Some 80000 Germans departed by the end of 1945 . Another 25000 residents of Gdańsk left the city in organised transports in 1946 and 1947, under the terms of the Potsdam accords. Altogether, some 3 million Germans were relocated from Poland. ${ }^{21}$

The first wave of deportations included mainly women, children, elderly and handicapped people and people unfit to work. Qualified specialists were retained for the time being. The chaos accompanying the first resettlement operation, caused by the absence of clear regulations on the organisation of transports, caused fear and mistrust among the Germans, but also gave them hope that they would remain in their home city. This hope was reinforced by their belief in the restoration of the prewar status quo and their conviction that Gdańsk would regain its status as Free City. Therefore, a part of the German population sought employment with municipal enterprises in order to receive Gdańsk residence permits, to which German employees and their families were entitled until such time as Polish specialists were found. But at the same time, there was a converse phenomenon - evasion of labour to which the Germans were compelled, the lowest possible punishment for all the cruelty suffered by Poles during the war. Holding the Germans collectively responsible was a natural reaction after the years of murder, moral harm and social degradation. The disgust and hatred that was concentrated among the civilian population after the war made some deportees feel that the Poles were responsible for their misfortunes, the loss of their country and property. ${ }^{22}$ There is no doubt that eviction from one's home caused major trauma, ${ }^{23}$ but one cannot ignore the fact that this was the result of a war started by Nazi Germany. Initial evasion of deportation was also caused by fears of being sent to Siberia.

When the war front had settled, the situation of the German population depended largely on the decisions and actions of the Soviets. Their behaviour ranged from brutal rape, murder and robbery on the one

19 Leszek Kosiński, "Przeobrażenia demograficzne na Ziemiach Zachodnich," in Przemiany społeczne na Ziemiach Zachodnich, ed. Władislaw Markiewicz and Paweł Rybicki (Poznań: Instytut Zachodni, 1967), 90-91.

20 Maciej Hejger, Polityka narodowościowa władz polskich w województwie gdańskim w latach 1945-1947(Słupsk: Wyższa Szkoła Pedagogiczna, 1998), 61.

21 For more about the resettlement of the German population from Poland, see Bernadetta Nitschke, Wysiedlenie czy wypędzenie? Ludność niemiecka w Polsce w latach 1945-1949 (Toruń: Wydawnictwo Marszałek, 2000); Stanisław Jankowiak, Wysiedlenie i emigracja ludności niemieckiej w polityce władz polskich w latach 1945-1970 (Warsaw: Instytut Pamięci Narodowej, 2005).

22 Edmund Dmitrów, Niemcy i okupacja hitlerowska w oczach Polaków. Poglądy i opinie z lat 1945-1948 (Warsaw: Czytelnik, 1987).

23 Grzegorz Brzozowski, Walczą z trauma, in Wypędzenia i co dalej? Materiały z seminarium polsko-niemieckiego dla studentów. Vertreibungen und was weiter? Beiträge eines deutschpolnischen Seminars für Studierende, eds. Anna Sophia Pappai, Micha Oskar Pec, and Krzysztof Marcin Zalewski (Warsawa: Wydawnictwo DiG, 2006), 48-49. 
hand to protecting the German population on the other. In the tri-national conflict that emerged between the Poles, Germans and Russians after the war, one group sometimes tried to impose its interests and win advantages at the expense of the other groups. In the case of the Germans, this often involved arranging Soviet protection against intimidation by Polish settlers and officials. The security services reported cases where the Germans received favourable treatment and were allowed to remain in Poland. Those unfit for work, elderly people and women were in a dramatic situation; they were evicted from their homes and left to vegetate among the ruins of Gdańsk. ${ }^{24}$

Source materials also report cases where the Soviets stirred up the German population against the Poles and the decrees of the Polish administration. For many months, some places near Gdańsk were inhabited mainly by Germans enjoying the protection of the Soviet forces. For example, in August 1945 in the district of Łostowice there were 2048 Germans and only 181 Poles. The head of the district was probably a German, backed by Soviet troops. ${ }^{25}$ The chief executive of Gdańsk county described this situation thus:

Owing to the absence of Poles in this area, administration is very difficult here, and the Germans are rebellious and have been emboldened by the Soviets [...]. Not seeing any representatives of Poland, they are oblivious to the phenomena and changes that have actually occurred. ${ }^{26}$

In many cases, Soviet protection delayed decisions to leave the city. But in the meantime, the number of Polish settlers reached 70000 at the end of 1945 , creating a disastrous situation with supplies and accommodation. The authorities of Gdańsk warded off general hunger and a typhoid epidemic, blaming this on the German population. In fact, weak and undernourished Germans were more susceptible to infectious diseases. Various solutions were sought. Contrary to regulations, sick people were placed in German transports or taken to the "Narwik" camp, where the German population, not just of Gdańsk but also from neighbouring places, was herded. For Germans, the camps were a halfway house between eviction from home and transportation away from Poland. Here, deportees were prepared for their journey, whilst others were accommodated in the barracks as a compulsory labour force for work in neighbouring farms. Only a few Germans were lucky enough to obtain medical care in a nearby hospital. As a result of the actions of the local authorities, people belonging to the indigenous population who were wrongly identified as Germans also ended up in this camp. ${ }^{27}$

More or less from the middle of 1946, those Gdańsk Germans still living in the city gradually lost hope of any changes. The trial of 11 employees of the Stutthof concentration camp, including 5 women, and their execution

24 Sylwia Bykowska, "Problem ludności niemieckiej w Gdańsku w pierwszym okresie po zakończeniu II wojny światowej. Rekonesans badawczy," Rocznik Polsko-Niemiecki 25, no. 2 (2017): 33-54.

26 State Archives of Gdańsk (APG), 1167/238, Sprawozdanie starosty powiatowego gdańskiego, August 16, 1945, 374-377.

27 Gedanopedia, www.gedanopedia.pl/gdansk/?title=OBOZY_W_NARWIKU,accessed: January $11,2018$. 
on July 4, 1946, represented a breakthrough. The public execution of these German criminals, arranged by the authorities, must have made an impression, and not only on the thousands of spectators, the "new" Polish residents of Gdańsk. All over Poland, the press carried reports on the trial and execution, describing Gdańsk as the Nuremberg of Poland.$^{28}$ In the summer of 1946, the city authorities noted a surge in the number of Germans demanding transports to take them across the Oder river. This marked the symbolic end of German Gdańsk, whose agony in subsequent years was alleviated by Polonisation and the creation of a new civilisation and economy.

Closely linked to the deportation of Germans was the ethnic vetting campaign, intended to regulate ethnic relations throughout the "regained territories." About one million of inhabitants of the territories annexed to Poland consisted of the indigenous population referred to above, some of whom had no clear-cut ethnic-national identity. ${ }^{29}$ To discover who was really German and who was Polish, vetting was commenced, which determined whether the vetted person could remain in Poland or whether, having been deemed a German national, he would have to move to Germany. In Gdańsk, this process of ethnic segregation commenced in July 1945, involving former residents of the Free City of Danzig whose status under the terms of the vetting regulations was equal to German citizenship. ${ }^{30}$ The vetting involved creating a clear demarcation between the German and Polish population. It took the form of an administrative action before a Vetting-Rehabilitation Board for Gdańsk Poles, composed of pre-war activists. They had no easy task, for not everyone could be classified in terms of nationality straightaway. If a part of the indigenous population had preserved close associations with Poland, another part had lost them completely as a result of long-term Germanisation. Before the war, Gdańsk was one of the most Nazified cities of the Third Reich. But regardless of that, the city's inhabitants approached the question of nationality with reserve. A more important forum of collective identity for them was the pre-war Free City of Danzig. Both its German and its Polish inhabitants were so closely attached to their city that for many years after the war they called themselves "Gdańsk people" (gdańszczanie). Others, despite being of Polish descent, felt no connections with Poland. Polish authorities conducted heated debates on the criteria to be applied by the vetting boards when separating the Polish population from the German population which was due for deportation. The principle of so-called broad vetting prevailed, resulting from the political need to rapidly make the "regained territories" Polish. This involved including in the Polish nation not just those with a clear national consciousness, but also those "who had been forcefully separated from the Polish state and thrust into the German nation through terror." ${ }^{131}$ At the same time, it was realised that the mere granting

28 Stutthof i Norymberga, Dziennik Bałtycki no 128, May 11, 1946; Sylwia Bykowska, "Zbrodnia i kara jako rytuał. Gdański proces stutthofskich zbrodniarzy," Rocznik Polsko-Niemiecki 23, no. 1(2015): 49-87. północnych w latach 1945 - 1960 (Słupsk: Wyższa Szkoła Pedagogiczna 1999). województwie gdańskim po Il wojnie światowej(Gdańsk: Instytut Kaszubski, 2012).

31 Archive of New Files (AAN), 199/765, Regulamin powoływania i funkcjonowania Obywatelskich 
of citizenship was not the end of the matter, but merely the start of a long road for former German citizens towards Polishness. Becoming Polish does not mean formal residence within the country's borders, but an emotional attachment to the Polish nation and a creative process of development of the nation and of the reconstruction of the state. ${ }^{32}$

A similar view of the vetting of the indigenous population was taken by the authorities of Gdańsk, who called for a tolerant treatment of applicants:

It is necessary to apply a liberal and lenient approach if an applicant is undeniably of Polish descent and is likely to become a decent citizen of Poland over the course of time. ${ }^{33}$

Knowledge of the Polish language as one of the more important qualifications of Polish nationality raised doubts, although many people spoke both Polish and German. Using German after the war caused utmost disgust and hatred among Poles. ${ }^{34}$ But there were people who tried to understand and explain the complicated ethnic relationships in Poland and further in Pomerania. The following extract of an article in the local press is an example:

\begin{abstract}
We cannot expect collective heroism from the many generations and hundreds of thousands of residents here who have preserved their Polishness. When resolving mass issues, one must apply an average measure - in this case an average feeling of sensitivity and perseverance in our nationhood. (...) We must take into account the objective circumstances that made it difficult to nurture and preserve Polish nationhood. Although a lack of Polish is an extenuating circumstance, it is not the decisive question when considering rehabilitation, for there have been cases where a family who demonstrated Polish origin but spoke no Polish was rehabilitated, but a family who spoke fluent Polish was not. ${ }^{35}$
\end{abstract}

Regarding vetting as an introduction to Polonisation policy, an effort was made to keep most of the indigenous Polish population in the annexed areas in Poland. ${ }^{36}$ There was a similar issue with regional ethnic groups - the Kashubians, Mazurians and Silesians.

It was necessary to prove to the vetting board that one was of Polish descent and of use to the Polish nation, for example through participation in Polish organisations before the war. National attitudes during the war were also important, for members of the Nazi party were disqualified from vetting. Those who passed the vetting procedure, i.e. their Polish descent had been established, received a special vetting certificate entitling them to Polish citizenship. But "in return," they had to sign a declaration of loyalty to the Polish nation and state. From the very start of communist rule, great importance was attached to the question of loyalty to the new authorities, for

\footnotetext{
Komisji Weryfikacyjnych, 1946, 3-12.

32 Ibidem.

33 APG, 1164/361, Pismo do Zarzą du Miejskiego w Elblągu, August 3, 1945, p. 36.

34 Piotr Perkowski, Gdańsk-miasto od nowa. Kształtowanie społeczeństwa i warunki bytowe w latach 1945-1970 (Gdańsk: Słowo/Obraz Terytoria, 2013), 57.

35 Jak pracuje Komisja Rehabilitacyjna w Gdańsku, "Dziennik Bałtycki", 1945, no 162, 5.

36 APG, 1164/362, Pismo przewodniczącego Wojewódzkiej Komisji Weryfikacyjnej do Starostwa Powiatowego w Stargardzie Gdańskim, July 22, 1946, 317.
} 
we know that in order to survive, authoritarian governments require evidence of support from the citizens, regardless of their internal convictions which, needless to say, do not count in the long run. What counts are external, public demonstrations of loyalty. It seems that throughout the territories that had once belonged to Germany, the need to reach a decision on nationality was exploited in order to forge a link between the border communities and the new authorities. In return for recognising the Polishness of these communities and garnering them Polish citizenship, and saving them from deportation at the same time, the authorities expected their political support. Many researchers demonstrate that it is in these "regained territories," where different communities were amalgamating into a new society, that the communist authorities could count on the greatest support. An absence of common traditions joining these communities helped them build a new life using that which the Polish administration had to offer. ${ }^{37}$

But efficient ethnic vetting was also hampered by formal obstacles, for example it was often impossible to present documents because they had been lost in the turmoil of war. The solution was to appoint witnesses, but this did not always permit an objective decision because the vetting process was sometimes manipulated for the sake of personal gain. Sometimes, officials eager to obtain post-German property arranged the deportation of persons who had clearly declared their Polishness so that they could take over their accommodation and seize their goods. On the other hand, there were Germans who did not want to leave Poland, so they tried to convince the vetting board that they were Polish so that they could remain in Gdańsk. Sometimes too, instead of nationality, material considerations or conflicts with neighbours were used as a criterion on which to reach a decision regarding deportation.

As I said, the pre-war citizens of Gdańsk - Germans and Poles - were convinced that the city's pre-war status quo as a Free City would soon be restored. Therefore, expecting the pre-war situation to be restored, they tried to evade vetting. However, under pressure from the mass influx of Polish settlers, who assumed the paces of the departing Germans, it became necessary to clearly decide which nation and state they belonged to. At the end of 1948, almost 13500 indigenous residents of Gdańsk had been vetted and recognised as Polish citizens, somewhat over $9 \%$ of the population. But over 2000 applications for vetting had been rejected. ${ }^{38}$

A separate issue was the German National List (Volksliste), which had been a tool of Germanisation during the war. ${ }^{39}$ With the start of World War II, the population of Gdańsk and of the Polish northern and western territory annexed to the Third Rich received German citizenship. Holders of Polish citizens, including officials in the Free City of Danzig, could decide whether or not to enrol in the Volksliste, but if they refused, they faced possible

37 Cf. Padraic Kenney, Budowanie Polski Ludowej. Robotnicy a komuniści 1945-1950, trans. Anna Dzierzgowska (Warsaw: Wydawnictwo W.A.B. 2015), 171-187.

38 Sylwia Bykowska, "Problem osadnictwa w Gdańsku w pierwszych latach po zakończeniu II wojny światowej," Zapiski Historyczne 4 (2017): 81-109.

39 Leszek Olejnik, Zdrajcy narodu? Losy volksdeutschów w Polsce po II wojnie światowej (Warsaw: Wydawnictwo Trio, 2006). 
reprisals, including interment in the camp at Stutthof mentioned above. The essence of Germanisation was the displacement of the Polish population by force, and the success of this operation guaranteed a life on the borderlands, at the point of contact of two cultures - Polish and German. In the opinion of politicians in the Third Reich, the latter was more attractive.

At the end of the war, it was time to grant or restore Polish civic rights to those who had lost them as a result of Nazi ethnic policy. On May 6, 1945, the law entitled On the exclusion of hostile elements from Polish society was passed. This provided the basis for the rehabilitation campaign. Pursuant to a decree of September 13, 1946, persons declaring German nationality were stripped of Polish citizenship. They were subject to compulsory deportation and their property was subject to confiscation. ${ }^{40}$

Settling the question of citizenship was very important, mainly for the sake of preserving one's civic and property rights. For many people, approval of their application for vetting or rehabilitation was a fundamental matter, allowing them to take active part in political, professional or social life. Waiting to obtain full civic rights under the post-war conditions was a battle for personal honour in the newly-emerging society, whose core comprised settlers from central and south-eastern Poland.

For those with a high sense of Polish nationhood, both these procedures (rehabilitation and vetting) were a humiliation, especially after their harsh experience under the German occupation. Instead of rejoicing in the defeat of the Germans, they had to explain to the new authorities the mechanisms of Third Reich policy in Pomerania, including the problem of extermination, followed by Germanisation. One need only think of the capture of Pomerania by the Soviets and the behaviour of the incoming settlers to appreciate the growing animosity of the local Polish population towards the new reality.

After 1945, Germanisation and rehabilitation aroused strong emotions and misunderstanding among those Poles who had not experienced this form of Nazi discrimination. The authorities did not consider the fact that in the areas incorporated into the Third Reich there was a general duty to enrol in the Volksliste and that refusal to do so could mean death. They did not consider the reasons why people enrolled on the list, nor the differences in attitudes towards Poles. The Volksdeutsche were often made the scapegoats for the nightmare of German occupation. Treated as Germans, they experienced terror, violence and deportation. It is a paradox of history that during the war the inhabitants of Pomerania were persecuted for being Polish, while after the war the so-called Volksdeutsche were accused of na-

\footnotetext{
40 The end of hostilities and the unconditional capitulation of the Third Reich commenced the period of settlement for German atrocities against mankind and war crimes. The occupied countries passed special criminal legislation to deal with collaborators. The first legal instrument meant to liquidate the effects of the war and the occupation was the decree by the Polish Committee of National Liberation of August 31, 1944, On punishment for FascistHitlerite criminals guilty of murdering and tormenting the civilian population and prisonersof-war and for traitors to the Polish Nation. It was intended to settle scores for war crimes and for various forms of collaboration with the Germans during the war. See Andrzej Pasek, Przestępstwa okupacyjne w polskim prawie karnym z lat 1944 - 1956 (Wrocław: Wydawnictwo Uniwersytetu Wrocławskiego 2002), 13.
} 
tional treason, excluded from public life, discriminated at work and deprived of food rations or benefits. In Gdańsk itself, only a limited number of people were enrolled on the list because most of the population had German citizenship. An examination of the records of people who applied for rehabilitation after the war in order to acquire Polish citizenship reveals that 1511 persons on the territory of the Free City of Danzig enrolled themselves in the Volksliste. Mieczysław Okęcki, voivode of Gdańsk, also pointed to the problem of treating Poles who had been forced to enrol in the Volksliste as Germans, therefore in April 1945 he issued a directive commencing a campaign of rehabilitation. Applicants for this had to sign before the authorities a declaration of loyalty to the nation and the democratic state of Poland. Rehabilitation also occurred within the city administration, where one had to prove that one had a pro-Polish attitude during the war. A total of 1970 people were rehabilitated in Gdańsk by February 1947.41 Both operations carried out in the name of the national idea, Germanisation and rehabilitation (often assuming the form of social lynching), left a permanent mark on the lives of entire communities. The task of integrating people on the Volksliste with the remainder of society after the war was sometimes problematic; many people gave up living in Poland and preferred to move to Germany. As late as the 1980s the West German authorities recognised an Ausweis (issued to persons who had been enrolled on the Volksliste) as proof of German citizenship. ${ }^{42}$

The above procedures of ethnic segregation served to disintegrate local communities, including indigenous Gdańsk people. Neighbours considered Polish by their communities, but dismissed as Germans by the authorities, were removed and their places were taken by settlers from central Poland and from the lands lost to the USSR. Many indigenous residents of Gdańsk lost their homes and the farmers in the surrounding farmlands lost their farms, which were subsequently handed over to the settlers as post-German property. This gave rise to distrust, animosity and disputes between the social groups of which the new society of Gdańsk was being created. There was rivalry, sometimes brutal, for access to goods, housing, jobs and movable property. Under the influence of the pioneering ideology propagated by the state, the indigenous residents of Gdańsk, the original inhabitants and owners in this area, became less and less "visible" during the ongoing resettlement operation. They were thus assigned to a losing position because without civic rights, they had no right to their original apartments, farms, etc. The decree of March 30, 1945 that created the voivodship of Gdańsk annulled the previous legislation in force in the Free City, including property rights.

The new society of Gdańsk emerged out of different regional groups representing divergent attitudes and culture. The wartime experience of these groups in the various parts of occupied Poland was also different. ${ }^{43}$

41 APG, Municipal People's Council and City Council of Gdańsk, 1165/1110, Rejestr deklaracji wierności.

42

Piotr Madajczyk, "Niemcy," in Mniejszości narodowe w Polsce. Państwo i społeczeństwo polskie a mniejszości narodowe w okresach przełomów politycznych (1944-1989), ed. Piotr Madajczyk (Warsaw: Instytut Studiów Politycznych PAN, 1998), 71.

43 Particularly difficult to accept for settlers arriving in Pomerania was the fact that many local 
To a major extent, this new society emerged from migration, enforced and voluntary. Enforced migration was the so-called repatriation of Poles from former Polish lands on the other side of the Bug river, i.e. the lands lost to the USSR. ${ }^{44}$ It is worth pointing out a certain similarity between the fortunes of the German population and those of the population of Polish lands lost to the USSR. These people, just like the Germans, had lost their homeland and had been forced to leave their neighbourhoods. This common situation sometimes created bonds of kindness, understanding and mutual help in 1945, when history combined their fortunes very briefly. But the settlers from central Poland sought voluntarily, independently and without any pressure from the top, opportunities for social and economic advancement in the "regained territories." With its shipping industry, Gdańsk attracted hordes of young people hungry for success.

The national state became the pillar of the post-war order. In the name of the national idea, a new international order was introduced in Europe, not just affecting the history of nations, but also directly shaping the fortunes of regions, cities, local communities and individuals. The national idea was also the driving force of demographic changes in Gdańsk after the city's inclusion within Poland's borders after the war.

The three operations that marked a "new beginning" for the entire population of Gdańsk - deportation, vetting and settlement - interacted with each other. The fortunes of the indigenous Polish population were to a considerable extent dependent on the situation of Gdańsk Germans and on their relocation beyond the Oder river. Parallel to this, the effectiveness of the vetting was determined by the influx of settlers to Gdańsk and their attitudes. Thus, the social status of the indigenous residents of Gdańsk was determined by their external identity, i.e. an assessment of their usefulness to the nation by officials and settlers. That means they could have been identified as Germans and forced to move beyond the Oder, or they could have won acceptance from the newly-arrived "genuine" Poles and, together with theme, create a new Poland.

Eventually, nationalist ideology served to integrate not just local communities, but the entire Polish nation. The complete elimination of ethnic minorities has not only altered Poland's demographic structure, but has also, combined with the heritage of communism, shaped a specific mentality which can still be felt among a part of society and which manifests itself as distrust and fear of "foreign" non-Poles.

inhabitants had been enrolled in the Volksliste and had served in the Wehrmacht. For the circumstances in Pomernia during the war, see Bogdan Chrzanowski, Andrzej Gąsiorowski and Krzysztof Steyer, Polska Podziemna na Pomorzu w latach 1939-1945 (Gdańsk: Wydawnictwo Oskar, 2005), 52-63.

44 About two million Poles were compulsorily resettled, most of them in the "regained territories." Jan Czerniakiewicz, Repatriacja ludności polskiej z ZSRR 1944-1948 (Warsawa: PWN, 1987). 


\section{SOURCES}

1. Archiwum Państwowe w Gdańsku [State Archives of Gdańsk]: Państwowy Urząd Repatriacyjny, Oddział w Gdańsku [State Repatriation Office, Gdańsk Branch].

2. Archiwum Państwowe w Gdańsku [State Archives of Gdańsk]: Urząd Wojewódzki w Gdańsku [Voivodship Office of Gdańsk] Miejska; Rada Narodowa I Zarząd Miejski w Gdańsku [Municipal People's Council and City Council of Gdańsk].

3. Archiwum Akt Nowych $w$ Warszawie [Archive of New Files of Warsaw]: Ministerstwo Ziem Odzyskanych [Ministry of the Regained Territories].

\section{BIBLIOGRAPHY}

1. Berlińska, Danuta and Piotr Madajczyk. Polska jako państwo narodowe. Historia i pamięć. Warsaw-Opole: Instytut Studiów Politycznych PAN, 2008.

2. Brzozowski, Grzegorz. Walczą c z traumą. In Wypędzenia i co dalej? Materiały $z$ seminarium polsko-niemieckiego dla studentów. Vertreibungen und was weiter? Beiträge eines deutsch-polnischen Seminars für Studierende, edited by Anna Sophia Pappai, Micha Oskar Pec, and Krzysztof Marcin Zalewski. Warsaw: Wydawnictwo DiG, 2006.

3. Bykowska, Sylwia. Rehabilitacja i weryfikacja narodowościowa ludności polskiej w województwie gdańskim po II wojnie światowej. Gdańsk: Instytut Kaszubski, 2012.

4. Bykowska, Sylwia. "Zbrodnia i kara jako rytuał. Gdański proces stutthofskich zbrodniarzy." Rocznik Polsko-Niemiecki 23, no. 1(2015): 49-87.

5. Bykowska, Sylwia. "Problem ludności niemieckiej w Gdańsku w pierwszym okresie po zakończeniu II wojny światowej. Rekonesans badawczy." Rocznik Polsko-Niemiecki 25, no. 2 (2017): 33-54.

6. Bykowska, Sylwia. "Problem osadnictwa w Gdańsku w pierwszych latach po zakończeniu II wojny światowej." Zapiski Historyczne 4 (2017): 81-109.

7. Chrzanowski, Bogdan, Andrzej Gą siorowski, and Krzysztof Steyer. Polska Podziemna na Pomorzu w latach 1939-1945. Gdańsk: Wydawnictwo Oskar, 2005.

8. Czerniakiewicz, Jan. Repatriacja ludności polskiej z ZSRR 1944-1948. Warsaw: PWN, 1987.

9. Czubiński, Antoni. Polska i Polacy po II wojnie światowej (1945-1989). Poznań: Wydawnictwo Naukowe UAM, 1998.

10. Dmitrów, Edmund. Niemcy i okupacja hitlerowska w oczach Polaków. Poglądy i opinie z lat 1945-1948. Warsaw: Czytelnik, 1987.

11. Drzycimski, Andrzej - Westerplatte: misja specjalna. Gdańsk: Oficyna Gdańska, 2015.

12. Eberhardt, Piotr. Między Rosja a Niemcami. Przemiany narodowościowe w Europie Środkowo-Wschodniej w XX w. Warsaw: PWN, 1996.

13. Jankowiak, Stanisław. Wysiedlenie i emigracja ludności niemieckiej w polityce władz polskich w latach 1945-1970. Warsaw: Instytut Pamięci Narodowej, 2005.

14. Hejger, Maciej. Polityka narodowościowa władz polskich w województwie 
gdańskim w latach 1945-1947. Słupsk: Wyższa Szkoła Pedagogiczna, 1998.

15. Hejger, Maciej. Przekształcenia narodowościowe na ziemiach zachodnich i północnych Polski w latach 1945-1959. Słupsk: Wydawnictwo Naukowe Akademii Pomorskiej, 2008.

16. Kenney, Padraic. Budowanie Polski Ludowej. Robotnicy a komuniści 19451950. Translated by Anna Dzierzgowska. Warsaw: Wydawnictwo W.A.B., 2015.

17. Kersten, Krystyna. Jałta w polskiej perspektywie. Warsaw: Wydawnictwo ANEKS \& NOWa, 1989.

18. Kosiński, Leszek. "Przeobrażenia demograficzne na Ziemiach Zachodnich." In Przemiany społeczne na Ziemiach Zachodnich, edited by Władislaw Markiewicz and Paweł Rybicki, 78-131. Poznań: Instytut Zachodni, 1967.

19. Madajczyk, Piotr. Czystki etniczne i klasowe w Europie XX wieku. Szkice do problemu. Warsaw: Instytut Studiów Politycznych PAN, 2010.

20. Madajczyk, Piotr. Niemcy, In Mniejszości narodowe w Polsce. Państwo i społeczeństwo polskie a mniejszości narodowe w okresach przełomów politycznych (1944-1989), edited by Piotr Madajczyk. Warsaw: Instytut Studiów Politycznych PAN, 1998.

21. Mikos, Stanisław. Wolne Miasto Gdańsk a Liga Narodów: 1920-1939. Gdańsk: Wydawnictwo Morskie, 1979.

22. Nitschke, Bernadetta. Wysiedlenie czy wypędzenie? Ludność niemiecka w Polsce w latach 1945-1949. Toruń: Wydawnictwo Marszałek, 2000.

23. Olejnik, Leszek. Zdrajcy narodu? Losy volksdeutschów w Polsce po II wojnie światowej. Warsaw: Wydawnictwo Trio, 2006.

24. Osękowski, Czesław. Społeczeństwo Polski Zachodniej i Północnej w latach 1945-1956: procesy integracji i dezintegracji. Zielona Góra: WSP, 1994.

25. Osękowski, Czesław and Grzegorz Strauchold, eds. "Ziemie Odzyskane" po drugiej wojnie światowej. Zielona Góra: Oficyna Wydawnicza Uniwersytetu Zielonogórskiego, 2015.

26. Pasek, Andrzej. Przestępstwa okupacyjne w polskim prawie karnym z lat 1944 - 1956. Wrocław: Wydawnictwo Uniwersytetu Wrocławskiego, 2002.

27. Perkowski, Piotr. Gdańsk-miasto od nowa. Kształtowanie społeczeństwa i warunki bytowe w latach 1945-1970. Gdańsk: Słowo/Obraz Terytoria, 2013.

28. Reichling, Gerhard. Die Deutschen Vertriebenen in Zahlen. Teil I: Umsiedler, Verschleppte, Vertriebene, Aussiedler 1940-1985. Bonn: Kulturstiftung der Deutschen Vertriebenen, 1986.

29. Romanow, Zenon. Polityka władz polskich wobec ludności rodzimej ziem zachodnich i północnych w latach 1945 - 1960. Słupsk: Wyższa Szkoła Pedagogiczna, 1999.

30. Sakson, Andrzej. Mazurzy - społeczność pogranicza. Poznań: Instytut Zachodni, 1990.

31. Snyder, Timothy. Bloodlands. Europe between Hitler and Stalin. New York: Basic Books, 2010.

32. Snyder, Timothy. Skrwawione ziemie. Europa między Hitlerem a Stalinem, translated by Bartłomiej Pietrzyk, Warsaw: Świat Książki, 2011.

33. Strauchold, Grzegorz. Autochtoni polscy, niemieccy, czy...od nacjonalizmu do komunizmu (1945-1949). Toruń: Wydawnictwo Adam Marszalek, 2001. 